\title{
Performance and Nutrient Digestibility of Rabbit Fed Urea Treated Cowpea Husk
}

\author{
M. Mohammed and Jamala, G.Y ${ }^{*}$ \\ Adamawa State College of Agriculture, PMB 2088 Ganye, Nigeria
}

\begin{abstract}
This study was conducted to evaluate the effect of varying levels of urea treated and untreated cowpea husk on the performance of weaned rabbit. Sixteen (16) breed weaner rabbits of both sexes, 6-8 weeks old with an average initial weight of $833 \mathrm{~g}$ were randomly distributed to four dietary treatments with 4 rabbits per treatment. The experiment lasted for a period of six weeks. Two diets were formulated in which cowpea husk was included at 40\% (untreated control), 40,50 and 60\% urea treated cowpea husk at 4\% designed as diet 1, 2, 3 , and 4 respectively. The rabbits were weighed weekly to observe body weight changes, fresh water was supplied ad libitum and $100 \mathrm{~g}$ of feed were offered to each rabbit daily. The results showed that daily feed intake, dry matter intake, feed conversion ratio and crude protein intake were significantly different $(p<0.05)$, while the daily weight gain did not show much variation ( $p>0.05$ ). Three mortalities were recorded during the experiment, one in treatment three and, two in treatment four. Mortality was highest in treatment four $(60 \%$ inclusion level). It can be deduced from this study that supplementing rabbit diet with $4 \%$ urea used for the treatment at $40 \%$ level of inclusion is safe to the rabbit if properly and uniformly added. Further research is necessary at higher treated levels of urea to reduce the toxic effect.
\end{abstract}

Keywords: Nutrition, Rabbits, Performance, Urea, Cowpea Husk

\section{Introduction}

World food productions are consistently lower than human population growth despite national Bilateral and international requirement of man and his livestock especially in the third world countries (Onwuka et al. 1995). Perhaps the most important nutritional problem is that of inadequate intake of protein especially that of animal origin (Fielding, 1991). The ever increasing human population coupled with poor performance of the available livestock is some of the major factors limiting the supply of animal protein in the developing countries; this is partly due poor genetic make-up and inadequate feeding (Peters, 1988).

The strategies that have been suggested to address the problem of shortage of animal protein in the developing countries include the production of short generation time animals such as rabbit, poultry and pigs (Ekpenyong and Biobaku, 1986). The rabbit Oryctolagus curriculus is a pseudo-ruminant with high reproduction rate (age at maturity 4-12 months, gestation period 31-32 days, litter-size ranges from 3-12 young) which is potentially more reflective than other livestock at converting forage into meat, with high protein, low fat energy and cholesterol content (Agege. 1994). The rabbit being a non-ruminant herbivore can be fed locally on variable feedstuff of no direct nutritional value to human beings. Weeds, grass forage, vegetable roots, coarse grasses and house wastes as well as by-products like rice, beans and corn bran (Aduku and Olukosi, 1990). Despite the promising potentials of the rabbit as a meat and for producing animal protein, a number of factors presently limit the profitability of rabbit enterprise. These are related to problems of nutrition, diseases, genetic and high labor requirement for intensive rabbit production (Rabbit hand book, 1978).

One of the major factors responsible for the slow progress of rabbit industry in Nigeria and Adamawa state in particular is the non-availability of good quality pellet. Sometimes where it is available, the cost is unaffordable. As a result people resort to using locally available feeds for rabbit management. As regards feeding, though the rabbits require protein, it becomes highly imperative to study how rabbit could be raised cheaply taking advantage of their ability to utilized urea treated cowpea husk and still meet the excellent performance expected in terms of growth and reproduction. Although, literature on rabbit feed and feeding have shown, that rabbits were fed on a wide range of natural forage, crop residues and even kitchen waste, the evaluation of the performance of rabbit on urea treated and untreated cowpea husk become very important because of the scarcity and high cost of rabbit feeds in the State. Agege, (1994) found out that rabbits can utilize a fairly wide range levels of dietary fiber between $10-22 \%$ crude fiber for growth and maintenance.

\section{Treatment of Straws with Urea}

Blood et al. (1989) reported that urea has been introduced as feed additives for ruminants to provide a cheap protein substitute. It is also used as fertilizer on crops and pasture fields and accidental access to the power or liquid form of the compound can cause severe mortalities. Urea should be given in such a way as to slow down its rate of breakdown and encourage ammonium utilization for protein synthesis. 
Urea is most effective when given as supplement to diets of low protein content particularly if the protein is resistant to microbial breakdown. The diet should also contain a source of readily available energy so that microbial protein synthesis is enhanced and wastage reduces. Although urea provides an acceptable protein source, there is evidence that deficiencies of the sulphur containing amino acid may occur (Mc Donald et al. 1989).

Urea is available in proprietary foods in several forms, it may be included in form of solid blocks, which also provides vitamin and mineral supplementation and contains a readily available source of molasses as the energy source and carrying a variable amount of mineral and vitamin supplementation are also in use. Where urea is included in concentrated diets thorough mixing is essential to prevent localized concentration, which may have toxic effects. A recent development in the feeding of urea has been its addition as a solution, which also supply some mineral and vitamin supplementation. Urea may be used in all classes of ruminants but is less effective in animals in which the rumen is not fully functional (M C Donald et al. 1989).

When straws are treated with alkali, the ester linkages between lignin and the cell wall polysaccharides, cellulose and hemicelluloses are hydrolyzed thereby causing the carbohydrate to become more available to the microorganism in the rumen. In the early process, (the Beckman Process) widely used, straw will be soaked for 1-2 days in dilute solution of sodium hydroxide then washed exhaustively to remove residual alkali. The process increase the digestibility of the straw but a considerable portion of the soluble nutrient is lost in washing. More recently, attention has concentrated on the so-called "dry process" in which the chopped or milled straw is treated with a relatively small volume of concentrated sodium hydroxide. In this process, in which the excess solution is not removed before feeding, the digestibility of the straw dry matter is increased (Mc Donald et al. 1989).

\section{Study Area}

\section{Materials And Methods}

The study was conducted at the Teaching and Research Farm of the Department of Animal Science, Federal University of Technology, Yola, Adamawa State, Nigeria. It lies between longitude $12^{\circ}$ and $12^{\circ} 28^{\prime}$ east of Greenwich and Latitude $9^{\circ} 16^{\prime}$ and $9^{\circ} 19^{\prime}$ North of the equator. The area is between 150 and $180 \mathrm{~m}$ above sea level.

The area has a tropical climate, marked by rainy and dry season. The rainfall commence in April and ends about October, while the dry season starts from October/November and ends April/May. It has an annual rainfall of about $700 \mathrm{~mm}-1600 \mathrm{~mm}$ per annum and average minimum temperature of $15.2^{\circ} \mathrm{C}$ and maximum of $39^{\circ} \mathrm{C}$ (Adebayo, 1997).

\section{Experimental Animals}

Sixteen mongrel weaner rabbits of both sexes ranging from 6-8 weeks of age with average initial weight of $822 \mathrm{~g}$ were randomly allocated to four (4) experimental diets. There were four rabbits per diet

\section{Management of the Rabbits}

The animals were housed individually in battery cages in a well-ventilated building. One week adjustment period was allowed. During that period, all the animals were fed the control diet, after which it was followed, by the respective treatment diets for the period of six (6) weeks. Prior to the experiment, the room was washed, dried and disinfected and left for (7) days before the animals were housed.

Strict hygiene was maintained throughout the period of the experiment. These include daily sweeping of the house every morning and evening, washing and refilling of drinkers with fresh clean water. Feeders were also washed daily and new feeds provided while the leftovers were weighed and discarded.

\section{Feed and Feeding}

The diets were formulated using Cowpea husk (fiber source) treated with $4 \%$ urea. The inclusion level were $40 \%$ as control (untreated) $40 \%$ (diet 2), 50\% (diet 3) and 60\% (diet 4) were incorporated into feed by mixing together the various ingredients as shown in table 2 . The rabbits were provided with $100 \mathrm{~g} /$ day of the diet at 0700 hours and the left over were collected and weighed before the next morning feeding. Clean cool water was provided to the rabbits ad libitum.

\section{Chemical Analysis}

$100 \mathrm{~g}$ of cowpea husk of the experimental diet were subjected to standard proximate analysis as described by association of official analytical Chemist (AOAC, 1980) to determine the dry matter (DM), crude fiber (CF), moisture content, crude protein (CP) ether extract and ash content. 
Data Analysis

Data collected were subjected to analysis of variance (ANOVA) as describe by Steel and Torrie (1960). Significant differences among the treatment means were separated using least significant difference (LSD).

\section{Proximate Analysis of experimental Diet}

\section{Results and Discussion}

The result of proximate analyses of the experimental diet is shown in Table 2. The result of the analyses shows that dry matter content was high in the cowpea husk (91.4\%). This can be compared to $91.58 \%$ DM of rice straw reported by (Siulapwa et al. 1998). The moisture content (8.6\%) obtained in this study was similar to that of Zaria, (2004) $8.7 \%$.

The crude protein was $46.3 \%$ while the crude fiber was $62.1 \%$. The total ash content in this study was $6.5 \%$, which is also, lower than $10.75 \%$ obtained by Igile (1995). The ether extract was 1.2 .

\section{Daily Feed Intake}

The result of daily feed intake is presented in Table 3. The result showed that there was significant difference $(p<0.05)$ between the treatment with highest feed intake in treatment $4(60.0 \%)$ and lowest in treatment 2 (44.14). This result was higher than $60 \mathrm{~g}$ live weight per days reported by Aduku and Olukoisi, (1990).

\section{Dry Matter Intake}

The result of the dry matter is shown in Table 3. An increase in the dry matter intake with increasing dietary fiber levels has been reported in rabbit (Abor-Ashour, and Barakat, 1986; Doma et al. 1995). The dry matter intake recorded in this study showed significant $(\mathrm{P}<0.05)$ different between treatments 3 (47.17) and 2 (44.19). There was no significant difference $(\mathrm{P}>0.05)$ in dry matter intake between treatment 1 (control) and treatment 4 (treated).

\section{Crude Protein Intake}

The crude and cowpea husk interaction effect on nutrient intake of different fed to the rabbits is presented in the Table 3. Rabbits fed on treatment $4(60 \%)$ cowpea husk consumed more dry matter than those fed on treatment $3(50 \%)$ and treatment $2(40 \%)$. However, the different was statistically significant $(p<0.05)$ among the treatment. There was no significant difference $(\mathrm{p}>0.05)$ between treatment $4(9.77)$ and treatment 1 (9.69).

\section{Daily Weight Gain (g)}

Table 3 shows the result of daily weight gain (g) of the rabbits. The daily weight gain is highest in treatment 4 (17.84) and lowest in treatment 1 (16.61). There was no significant difference $(\mathrm{p}>0.05)$ between the treatment means. However, the daily weight gain obtained on all the treatments was similar to the values (16.6017.90) report by Aduku et al. (1986) and Doma et al. (1995).

\section{Feed Conversion ratio}

The feed conversion is presented in Table 3 . The result shows that the highest feed conversion ratio was recorded in treatment 1 (4.33) and lowest in treatment 2 (2.97). Treatments 3(3.24) and treatment 4 (3.62) showed no significant difference and this is similar with the result obtained by (Doma et al. 1997) 3.5-4.4\%.

\section{Mortality Rate}

The result of mortality Rate (\%) is presented in Table 3 . The result shows that the highest mortality rate was recorded in treatment $4(0.5)$ and lowest in treatment $3(0.25)$. This could be as a result of high level inclusion $(60 \%)$ of treated cowpea husk. There was no significant different $(\mathrm{p}>0.05)$ between the treatments.

\section{Conclusion}

It can be concluded from the results of this study that supplementing rabbit diet with (4\%) urea treated cowpea husk at $40 \%$ inclusion level is safe to the rabbits if properly and uniformly added and mixed with the ingredients. Nevertheless, mortality was recorded in treatment $4(0.5)$ at $60 \%$ level of inclusion and in treatment $3(0.258)$ at $50 \%$ inclusion. Further research is necessary at higher inclusion level so that application can be accurately established to some level of safety. 
Table 1: The composition (\%) of the Experimental Diets

\begin{tabular}{|c|c|c|c|c|}
\hline Ingredients (\%) & & Diets (In & on Level) & \\
\hline & $\begin{array}{c}\mathrm{T} 1 \\
40 \% \text { (Untreated) }\end{array}$ & $\begin{array}{c}\mathrm{T} 2 \\
40 \% \text { (Treated) }\end{array}$ & $\begin{array}{c}\mathrm{T} 3 \\
50 \% \text { (Treated) }\end{array}$ & $\begin{array}{c}\mathrm{T} 4 \\
60 \% \text { (Treated) }\end{array}$ \\
\hline Maize & 36 & 36 & 26 & 16 \\
\hline GNC & 21 & 21 & 21 & 21 \\
\hline Cowpea Husk & 40 & 40 & 50 & 60 \\
\hline Salt $(\mathrm{NaCl})$ & 0.5 & 0.5 & 0.5 & 0.5 \\
\hline Bone Meal & 2.0 & 2.0 & 2.0 & 2.0 \\
\hline $\begin{array}{l}\text { *Premix } \\
\text { (Vitamin \& Minerals) }\end{array}$ & 0.5 & 0.5 & 0.5 & 0.5 \\
\hline Total & 100 & 100 & 100 & 100 \\
\hline
\end{tabular}

*Composition of vitamin premix per kg, vitamin A-1000.000 I.U $\quad \mathrm{D}_{3}-2,000.000$ I.U, E-15,000mg, $\mathrm{K}_{3}$ 2000mg. $\quad B_{6}-100 \mathrm{mg}$. $\mathrm{P}_{\mathrm{P}}-30,000 \mathrm{mg}, \mathrm{B}_{12}-10 \mathrm{mg}$, Folic Acid-100mg, C- 10,000mg, Chlorine 20,000mg and Ethoxyquine $10,000 \mathrm{mg}$

Table 2: Proximate Analysis of Experimental Diets (Cowpea Husk)

\begin{tabular}{ll}
\hline Components & Cowpea husk \\
\hline Dry matter $(\mathrm{g} / \mathrm{kg})$ & 91.4 \\
Moisture content $(\mathrm{g} / \mathrm{kg})$ & 8.6 \\
Ether extract $(\mathrm{g} / \mathrm{kg})$ & 1.2 \\
Crude fibre $(\mathrm{g} / \mathrm{kg})$ & 62.1 \\
Ash $(\mathrm{g} / \mathrm{kg})$ & 6.5 \\
Protein $(\mathrm{g} / \mathrm{kg})$ & 46.3 \\
\hline
\end{tabular}

Table 3: Performance of Rabbit Fed Urea Treated Cowpea Husk

\begin{tabular}{|c|c|c|c|c|c|c|}
\hline Parameters & $\begin{array}{l}\text { D1 } \\
40 \%(\% \%( \\
\text { untreated })\end{array}$ & $\begin{array}{l}\text { D2 } \\
40 \%(\text { treated })\end{array}$ & $\begin{array}{l}\text { D3 } \\
50 \%(\text { treated })\end{array}$ & $\begin{array}{l}\text { D4 } \\
60 \%(\text { treated })\end{array}$ & SE & LSD \\
\hline Daily feed intake (g) & $62.02 \mathrm{c}$ & $44.14 a$ & $49.90 \mathrm{~b}$ & $64.0 \mathrm{~d}$ & 0.70 & 1.53 \\
\hline Dry matters intake $(\mathrm{g})$ & $59.12 \mathrm{c}$ & $44.19 \mathrm{a}$ & $47.17 \mathrm{~b}$ & $60.4 \mathrm{c}$ & 0.74 & 1.63 \\
\hline Crude Protein intake (g) & $9.69 \mathrm{c}$ & $6.44 \mathrm{a}$ & $7.84 b$ & $9.77 \mathrm{c}$ & 0.54 & 1.18 \\
\hline Daily Weight Gain (g) & $16.61 \mathrm{a}$ & $16.97 \mathrm{a}$ & $16.67 \mathrm{a}$ & $17.84 \mathrm{a}$ & 0.73 & 1.59 \\
\hline Feed conversion ration & $4.33 \mathrm{c}$ & $2.97 \mathrm{a}$ & $3.24 \mathrm{ab}$ & $3.62 b$ & 0.24 & 0.53 \\
\hline Mortality (\%) & $0 \mathrm{a}$ & $0 \mathrm{a}$ & $0.25 \mathrm{a}$ & $0.5 \mathrm{a} 0.27$ & 0.59 & \\
\hline
\end{tabular}

Means with the same letter along the row are not significantly different $(\mathrm{P}<0.05)$

\section{References}

[1]. A.O.A.C (1980). Association of official Analytical Chemist Official methods of analysis $13^{\text {th }}$ edition Washington DC

[2]. Abow- Ashour, A.M and Barakat, M.A. (1986). Effect of Diet and Fibre levels on Digestibility.

[3]. Performance and caecal microbial activity in growing rabbits. Word Review of Animal Production 22(4) 52-59

[4]. Adebayo, A.A.and Tukur A.I. (1997). Adamawa State in Maps. Pub. Dept. of Geography, Federal University of Technology Yola. In Co-operation with Paraclete Pub. Yola-Nigeria Pp 8 - 26

[5]. Aduku a.o and Olukosi, D.o (1990). Rabbit Management in the Tropics, Living Faith Books Publishers Abuja FCT Pg 1 - 42

[6]. Agege, S. C. (1994). Rabbits and food supplement for rabbits and sensory properties of meat from rabbits fed rumen ingesta Journal of Agric. Tech. Vol. (2)

[7]. Blood, D.C. Radostitson, o.m. (1987). Diseases Caused by Chemical agents. A textbook of the Diseases of cattle, Sheep, pigs, Goats and Horses. Pp 1299-1300

[8]. Doma, U.D. Adegbola,T.A. and Yakubu, I.M (1999). Utilization of cowpea shell and maize cob as source of diet for rabbits. Tropical Journals of animal Science 2 (1) 27

[9]. EKpenyong, T.E. and Biokahy, J.O. (1986). Utilization of Offal meal as Replacement for Soya bean meal in diet of Rabbit. Journal of Department of Agric. Vol. 2, Federal Ministry of Agriculture Abuja

[10]. Fielding, D. (1993). Rabbit, Macmillan Edu. Ltd., London and Basingstoke Pp 1-101

[11]. Onwuka, C.F.I, Egbe, D.W., Udoh, B.I (1995). Milk Production Potential of Holstein Friesian Cattle in the derived Savannah Zone. Nigerian Journal of Animal Production. Vol 1

[12]. Peters, K.J. (1988). Potentials of Unconventional Livestock Production. World Reviewed of Animal Production. 24 (2): 71 - 84

[13]. Rabbit Handbook (1978). Leaflet 21020. Division of Agricultural Science. University of California. Pp 8

[14]. Steel. A.G. and Torrie, JW (1960). Principle and Procedure of Statistics. McGraw Hill Brok New York.

[15]. Zira, V.G. (2004). Analytical Laboratory Manual. Food Science Technology. Federal University of Technology, Yola. 